\title{
OVERVIEW OF ADDED VALUE-ADDED TAXES IN CONNECTION WITH COVID-19 VIRUS PLAGUE: VAT FACILITIES OR TAX INCENTIVES?
}

\author{
Andri Marfiana \\ Email: andri.marfiana@pknstan.ac.id \\ Politeknik Keuangan Negara STAN
}

\begin{abstract}
Abstrak
Penelitian ini bertujuan untuk menjelaskan bagaimana berlakuya PMK-28/PMK.03/2020, berkaitan dengan PPN DTP sebagai fasilitas atau insentif PPN. Terjadi kerancuan pemahaman antara fasilitas PPN berdasarkan UU PPN dengan insentif PPN DTP. Walaupun demikian, peneliti mencoba menjelaskan alasan Pemerintah memberikan insentif PPN. Penelitian ini menggunakan pendektan metode pengumpulan data studi literatur. Untuk metode analisis yang digunakan yaitu dengan pendekatan deskriptif kualitatif. Hasil penelitian menunjukan bahwa penerapan PMK-28/PMK.03/2020 didasari oleh inisiatif cepat Pemerintah dalam menanggulangi wabah Covid-19. Penelitian menunjukan bahwa insentif PPN DTP, tidak termasuk dalam fasilitas yang diatur oleh UU PPN. Akan tetapi, pemberian insentif ini berusaha tidak melanggar aturan yang diatur oleh UU PPN. Hal ini dapat terlihat mekanisme PK-PM tetap berjalan, walaupun atas beban PK ditanggung oleh Pemerintah. Dalam penelitian ini, dapat dismpulkan bahwa penerapan PMK28/PMK.03/2020 adalah pemberian insentif pajak dan bukan fasilitas PPN sebagaimana ditur dalam $U U P P N$.
\end{abstract}

Kata Kunci: Covid-19, Korona 2020, PMK-28 2020, Tax Incentive, Tax

\begin{abstract}
This study aimed to explain how the PMK-28 / PMK.03 / 2020 applies, relating to the PPN DTP as a $V A T$ facility or incentive. There is a confusion between the understanding of VAT facilities based on the VAT Act and the PPN DTP incentives. Nevertheless, the researchers tried to explain the government's reasons for providing VAT incentives. This research using a literature study data collection method. The analytical method used is a qualitative descriptive approach. The results showed that the application of PMK-28 / PMK.03 / 2020 was based on the government's rapid initiative in tackling the Covid-19 outbreak. Research indicates that PPN DTP incentives are not included in the facilities regulated by the VAT Law. However, the granting of this incentive tries not to violate the rules governed by the VAT Law. It can be seen by the mechanism of PK-PM still running, even though the government bears the burden of PK. In this study, it can be concluded that the application of PMK-28/ PMK.03 / 2020 is the provision of tax incentives and not VAT facilities, as stipulated in the VAT Law.
\end{abstract}

Keywords: Covid-19, Corona 2020, PMK-28 2020, Tax Incentive, Tax.

\section{INTRODUCTION}

Corona Virus, this virus outbreak, has shaken the world. This virus first appeared in the city of Wuhan in China in late 2019 ((Yang et al., 2020)). The emergence of the Coronavirus, better known as Covid-19, created a pandemic that swept across the world, including Indonesia. This virus makes the Indonesian economy also threatened, due to the existence of a "social distancing" policy followed by the issuance of Government Regulation number 21 (PP-21) 2020 concerning "Large-scale Social Restrictions in the
Context of Accelerating Handling of Corona Virus Disease 2019 (COVID-19)". To save the Indonesian economy, the government subsequently issued Government Regulation in place of Law Number 1 the Year 2020 (Perpu No.1 / 2020) concerning State Financial Policies and Financial System Stability for Handling Pandemic Corona Virus Disease 2019 (Covid-19) and To Face Threats that Harm National Economy and Financial System Stability. In addition to Perpu No.1 / 2020, the government also issued a Regulation of the Minister of Finance (PMK) RI number 28 / PMK.03 
/ 2020 concerning the Provision of Tax Facilities on Goods and Services Needed in the Context of Handling Corona Virus Disease 2019. This PMK was issued aiming to "support the availability of medicines, medical devices, and other support tools for the handling of the 2019 Corona Virus Disease pandemic (COVID-19)". The form of the facility provided is a Government-Borne Value Added Tax (VAT) incentive.

In PMK-28 / PMK.03 / 2020, it is stated that PPN DTP incentives are given for the supply of taxable goods (BKP) and utilization of chargeable services (JKP) context of handling the Corona pandemic. This incentive can help the procurement of medicines and other health support to deal with the Corona pandemic because there is no additional cost in the form of VAT. This PPN DTP remains outstanding but is paid by the government. The granting of PPN DTP was not the first time given by the government because previously, the PPN DTP had also been applied. An example is the DTP for Cooking Oil supply, to help the community due to the economic slowdown at that time. The PPN DTP facility is not regulated in Act Number 8 of 1983 concerning Value Added Tax of Goods and Services and Sales Tax on Luxury Goods as last amended by Act Number 42 of 2009 (VAT Law). The VAT Act only regulates VAT facilities in the form of VAT exempted, and VAT payable is not collected. The legal basis for providing PPN DTP incentives is a question, whether classified as a facility.

Since the granting of PPN DTP incentives is based on urgent conditions, this incentive is appropriate to deal with existing problems immediately. With this incentive, the government bears VAT owed for transactions that are categorized as receiving this incentive. So that entrepreneurs who do transactions are not burdened with VAT in conducting these transactions. With this DTP PPN incentive being given, the author tries to see a comparison, whether the stimulus is included in the facility criteria mentioned in the VAT Act. Considering the PPN DTP incentives are not mentioned in the VAT facility class in the VAT Act. The granting of PPN DTP incentives is also not the first time given by the government. Because of this, this learning was made as a writer's contribution to research on PPN DTP in Indonesia.

\section{RESEARCH METHODS}

The subject of this study was PPN DTP for submitting BKP and JKP required for handling the 2019 Corona Virus Disease pandemic, which was published through PMK-28 / PMK.03 / 2020. The subjects of this study will be compared with the VAT Facility based on the VAT Law and other DTP VAT that has been provided literature study data collection is the method used in this study. A literature study is a research conducted through data collection in the form of rules or scientific papers related to the object of research to solve a problem based on a critical and in-depth review of relevant library materials (Iskandar \& Sanusi, 2011). Wherefrom the existing literature, the author will make a detailed discussion about the subject matter. Data from the research then processed to find discuss the problem.

The data processing method used by the writer is qualitative. Qualitative methods are any data collection techniques (such as interviews) or data analysis procedures (such as categorizing data) that produce or use non-numeric data (Saunders, 2016). The author uses literature as data, where the information is non-numeric. This non-numeric data is then processed for analysis. So it is expected to discuss the existing problems.

\section{RESULTS AND DISCUSSION}

Results of Discussion on VAT Facilities in the VAT Act As discussed previously, in the VAT Law, there are only two VAT facilities, namely VAT payable Unpaid and VAT Exempted. The provision of these facilities is also limited by certain things that are considered strategic and in the interests of the public at large so that the provision of VAT facilities is not arbitrarily used by PKP in the transaction. Article 16B of the VAT Law states that "tax payable is not collected in part or in full or exempt from taxation, temporarily or permanently, for:

a. Activities in specific regions or certain places within the Customs Area;

b. The supply of certain Taxable Goods or the amount of certain Taxable Services;

c. Import certain Taxable Goods;

d. The use of certain Intangible Taxable Goods from outside the Customs Area within the Customs Area; and

e. Utilization of certain Taxable Services from outside the Customs Area within the Customs Area is regulated by Government Regulation ".

Furthermore, in the elucidation of $16 \mathrm{~B}$ article, it is mentioned that the ease of taxation regulated is limited to:

a. Encouraging the exports which are a national priority in Bonded Piling Places, or develop territories in Customs Areas that are specially formed for this purpose;

b. Tccommodating the possibility of agreements with other countries in the field of trade and investment, international conventions that have been ratified, and different international norms;

c. Encouraging the improvement of public health through the procurement of vaccines needed in the framework of the National Immunization Program;

d. Guarantying the availability of adequate equipment of the Indonesian National Army / Indonesian Police (TNI / POLRI) to protect the Republic of Indonesia's territory from external and internal threats;

e. Guarantying the availability of boundary data, and aerial photographs of the area of the Republic of Indonesia carried out by the Indonesian National Army (TNI) to support national defense; 
f. Increasing the nation's education and intelligence by providing general textbooks, holy books, and religious textbooks at relatively affordable prices for the community;

g. Encouraging the construction of places of worship;

h. Guarantying the availability of affordable housing for the grassroots, namely simple houses, very simple houses, and simple flats;

i. Encouraging the development of a national fleet in the field of land, water, and air transportation;

j. Supporting the national development by assisting the availability of strategic goods, such as silver handicraft raw materials;

k. Guarantying the implementation of government projects financed with grants and foreign loan funds;

1. Accommodating international custom in importing certain Taxable Goods that are exempt from import duty levies;

m. Help the availability of Taxable Goods and Taxable Services needed in the framework of handling natural disasters that are designated as national natural disasters;

n. Guarantying the availability of clean water and electricity required by the community; and

o. Ensuring the availability of public transportation in the air to encourage a smooth flow of goods and people in certain areas where there are no other adequate means of transportation, the ratio between the volume of products and people that must be moved with available means of transport is very high ".

The provision of VAT facilities is regulated further by a Government Regulation (PP). The following Exempt PPN facilities provided by the government:

Table 1.

List of VAT Facilities Exempt

\begin{tabular}{|l|l|}
\hline $\begin{array}{c}\text { The source } \\
\text { of law }\end{array}$ & \multicolumn{1}{|c|}{ Transactions Provided Facilities } \\
\hline PP-81/2015 & $\begin{array}{l}\text { Certain BKPs that are strategic, include: } \\
\text { - Factory machinery and equipment; } \\
- \text { BKP from natural resources (Marine, } \\
\text { Forestry, Animal Husbandry, and } \\
\text { Plantation); } \\
- \text { Silver handicraft raw materials; } \\
- \text { Simple Houses and/or Flats }\end{array}$ \\
\hline PP38/2003 & $\begin{array}{l}\text { submission of general textbooks, holy } \\
\text { books, religious textbooks, } \\
\text { Weapons/ammunition for TNI/POLRI, } \\
\text { Student Dormitory Houses, Polio } \\
\text { Vaccine, Sea/Lake/River Ships, Trains } \\
\text { and Parts, and Aircraft and Parts }\end{array}$ \\
\hline PP40/2015 & delivery of clean water by entrepreneurs \\
\hline
\end{tabular}

Source: PP Resume processed by yourself (2020)
In addition to Exempt VAT, the government has also provided Unpaid Debt VAT facilities. The following are examples of Unpaid VAT Unpaid facilities:

Table 2.

List of Unpaid VAT Facilities

\begin{tabular}{|c|l|}
\hline The source of law & \multicolumn{1}{|c|}{$\begin{array}{c}\text { Transactions Provided } \\
\text { Facilities }\end{array}$} \\
\hline PP-10/2012 & $\begin{array}{l}\text { Importing Goods to Free Areas } \\
\text { from other places in the Customs } \\
\text { Area through designated ports or } \\
\text { airports, utilization of intangible } \\
\text { BKP, and JKP to Free Areas from } \\
\text { other places in Customs Regions }\end{array}$ \\
\hline PP-106/2015 & $\begin{array}{l}\text { delivery of certain strategic } \\
\text { taxable goods in the form of an } \\
\text { anode slime to a taxable } \\
\text { businessman who carries out } \\
\text { business activities in the field of } \\
\text { processing an anode slime into } \\
\text { gold bars }\end{array}$ \\
\hline PP-50/2019 & $\begin{array}{l}\text { import and / or delivery of certain } \\
\text { transportation equipment and / or } \\
\text { delivery of services related to } \\
\text { certain transportation equipment } \\
\text { used by the TNI / POLRI and } \\
\text { Domestic } \\
\text { Companies }\end{array}$ \\
\hline
\end{tabular}

Source: PP Resume processed by yourself (2020)

with the VAT facility's granting, there is no output tax (PK) on the submission of BKP / JKP (PK = 0). Likewise, regarding crediting the input tax (PM) for the acquisition of BKP / JKP, for which the PPN facility is handed over. These two VAT facilities have different rules regarding crediting the input tax (PM) for obtaining the BKP / JKP. For VAT Exempted, PM for the acquisition cannot be credited. As for the Unpaid Charged VAT, the PM for the purchase can be credited to distinguish transactions that receive VAT facilities. It can be seen from the tax invoice document (FP). Every transaction made by PKP must be made FP, except for transactions that are not VAT outstanding. No exception for purchases that receive VAT facilities, PKP is still required to make a tax invoice. Each FP has a different number, with a format that is regulated by taxation provisions. Provisions regarding the form of FP are governed in PER-24 / PJ / 2012, based on these rules the FP numbering format is as follows:

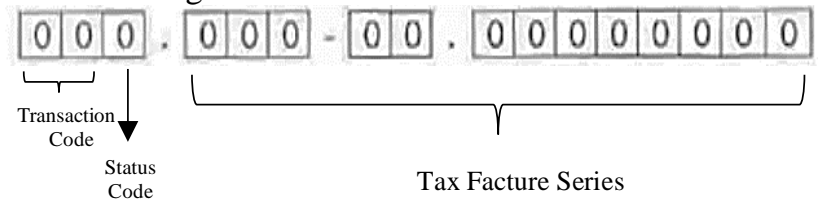

Picture of Table Figure 1. FP Numbering Format Source: Caption Attachment PER-24 / PJ / 2012 (2020) 
The FP numbering format in Figure 1 shows the difference between the released VAT facility and the Unpaid Unpaid VAT in the "Transaction Code." For transactions of VAT, facilities Exempt using the transaction code "08", whereas for transactions on the Unpaid VAT facility, the transaction code "07" is used. So if there is a PK with FP "08" transaction code, the PM for the acquisition cannot be credited. Conversely, if there is a PK with FP "07" transaction code, the PM of the acquisition can be credited to understand the different mechanisms of PK-PM for VAT facilities, it can be presented through illustrations. The illustrations for the Exempt VAT facility can be presented in the following table:

Table 3.

PK-PM Mechanism VAT Facilities Waived

\begin{tabular}{|c|c|}
\hline Acquisition & Nilai (RP) \\
\hline Acquisition Cost & 100.000 .000 \\
\hline $\mathrm{PM}$ & $\underline{10.000 .000}$ \\
\hline Acquisition Value & 110.000 .000 \\
\hline Delivery Price & Nilai (RP) \\
\hline Delivery Price & 110.000 .000 \\
\hline PK & - \\
\hline PM Cannot be credited & $\underline{10.000 .000}$ \\
\hline Delivery Value & $\overline{120.000 .000}$ \\
\hline Profit & Nilai (RP) \\
\hline Delivery Value & 120.000 .000 \\
\hline Acquisition Value & 110.000 .000 \\
\hline Profit & 10.000 .000 \\
\hline
\end{tabular}

Source: Personal Illustration

Whereas the PK-PM mechanism for the Unpaid VAT Debt facility can be presented in the following table:

Table 4.

PK-PM Mechanism for VAT Due Facilities Not collected

\begin{tabular}{|lc|}
\hline \multicolumn{1}{|c|}{ Acquisition } & Nilai (RP) \\
Acquisition Cost & 100.000 .000 \\
PM & $\underline{10.000 .000}$ \\
Acquisition Value & 110.000 .000 \\
\hline \multicolumn{1}{|c|}{ Delivery Price } & Nilai (RP) \\
Delivery Price & 110.000 .000 \\
PK & 110.000 .000 \\
PM Cannot be credited & Nilai (RP) \\
\hline PK VAT Debted & - \\
PK & 10.000 .000 \\
PM Nxtra VAT Pay & -10.000 .000 \\
\hline Pelivery Value & 110.000 .000 \\
Acquisition Value & -110.000 .000 \\
Extra VAT Pay & $\underline{10.000 .000}$ \\
Profit & 10.000 .000 \\
\hline
\end{tabular}

Source: Personal Illustration
From Table 3, it can be seen that if the VAT facility granted is VAT Exempt, PMs that cannot be credited will be charged to the selling price by PKP because the entrepreneur does not want to be disadvantaged. But even the final consumer still gets a profit of Rp1,000,000.00, because the delivery value should be the delivery price plus $10 \%$ VAT. In nominal terms, without the PPN facility being waived, the delivery price is IDR $120,000,000.00$ (Rp110,000,000.00 + IDR11,000,000.00). In terms of PKP itself, the PPN Exemption facility does not affect its profits. If the writer looks at Table 4, it can be explained that the Submission Value to the Final Consumer can be lower than the Exempt VAT. Consumers get a discount of Rp11,000,000.00 from the Normal Value of Rp121,000,000.00. While in terms of PKP, the profit generated is the same as VAT Exempted. But in terms of cash flow, PKP is disadvantaged, because even though the overpayment of VAT can be refunded, but it will take time to process the return.

\section{DTP VAT Discussion Results}

As already discussed in the DTP PPN definition, that PK owed for the submission of BKP / JKP is paid by the government. The government has provided PPN PPN incentives several times. Here are some lists that the author can summarize in the last ten years:

Table 5.

\section{Register VAT DTP}

\begin{tabular}{|l|l|}
\hline The source of law & \multicolumn{1}{|c|}{$\begin{array}{c}\text { Transactions Provided } \\
\text { Facilities }\end{array}$} \\
\hline $\begin{array}{l}\text { PMK- } \\
\text { 25/PMK.011/2010 }\end{array}$ & $\begin{array}{l}\text { Submission of Simple } \\
\text { Packaged Cooking Oil } \\
\text { Domestically for the 2010 } \\
\text { Fiscal Year }\end{array}$ \\
\hline $\begin{array}{l}\text { PMK- } \\
\text { 215/PMK.03/2010 }\end{array}$ & $\begin{array}{l}\text { Subsidized Oil Fuel, Biofuel } \\
\text { and Liquefied Petroleum Gas } \\
\text { (LPG) 3 (Three) Kilogram } \\
\text { Subsidized Fiscal Year 2010 }\end{array}$ \\
\hline $\begin{array}{l}\text { PMK- } \\
\text { 251/PMK.011/2010 }\end{array}$ & $\begin{array}{l}\text { Sharia Banking Murabahah } \\
\text { Transactions for Fiscal Year } \\
\text { 2010 }\end{array}$ \\
\hline $\begin{array}{l}\text { PMK- } \\
\text { 26/PMK.011/2011 }\end{array}$ & $\begin{array}{l}\text { Submission of Simple } \\
\text { Packaged Cooking Oil } \\
\text { Domestically for the 2011 } \\
\text { Fiscal Year }\end{array}$ \\
\hline $\begin{array}{l}\text { PMK- } \\
\text { 29/PMK.011/2011 }\end{array}$ & $\begin{array}{l}\text { Cooking Oil for the 2011 } \\
\text { Budget Year }\end{array}$ \\
\hline $\begin{array}{l}\text { PMK- } \\
\text { 88/PMK.011/2011 }\end{array}$ & $\begin{array}{l}\text { Subsidized Specific Fuel Oil } \\
\text { Subsidies and Liquefied } \\
\text { Petroleum Gas (Lpg) 3 (Three) } \\
\text { Kilogram Subsidized Tubes in } \\
\text { Fiscal Year 2011 }\end{array}$ \\
\hline
\end{tabular}




\begin{tabular}{|l|l|}
\hline PMK- & $\begin{array}{l}\text { Obtaining BKP: drugs; } \\
\text { vaccine; laboratory equipment; } \\
\text { detection equipment; personal } \\
\text { protective equipment; } \\
\text { equipment for patient care; and } \\
/ \text { or other supporting } \\
\text { equipment declared for the } \\
\text { handling of the 2019 Corona } \\
\text { Virus Disease pandemic } \\
\text { (COVID-19). } \\
\text { Obtaining JKP: required for } \\
\text { the handling of the 2019 } \\
\text { Corona Virus Disease } \\
\text { pandemic (COVID-19). } \\
\text { In the April 2020 Tax Period to } \\
\text { the September 2020 Tax } \\
\text { Period }\end{array}$ \\
\hline
\end{tabular}

Source: Self-processed PMK Resume (2020)

The granting of PPN DTP incentives did not result in a PK for submitting BKP / JKP to nothing. The PK-PM mechanism continues to run like a standard transaction, only the PK for the purchase is paid by the government. The government will issue funds originating from the State Budget (APBN) to pay PPN DTP. Sales that receive PPN DTP incentives are also required to make FP. Transaction code in the FP numbering of PPN DTP and Unpaid VAT is the same. The transaction code for VAT DTP is "07". PM acquisitions for transactions that receive PPN DTP incentives can also be credited. The following is a simulation of the PK-PM mechanism for DTP VAT transactions:

Table 6.

Mechanism of PK-PM PPN DTP

\begin{tabular}{|c|c|}
\hline Acquisition & Nilai (RP) \\
\hline Acquisition Cost & 100.000 .000 \\
\hline $\mathrm{PM}$ & 10.000 .000 \\
\hline Acquisition Value & 110.000 .000 \\
\hline Delivery Price & Nilai (RP) \\
\hline Delivery Price & 110.000 .000 \\
\hline PK & \\
\hline PM Cannot be credited & 110.000 .000 \\
\hline VAT Debted & Nilai (RP) \\
\hline PK & - \\
\hline PM & 10.000 .000 \\
\hline Extra VAT Pay & -10.000 .000 \\
\hline $\begin{array}{l}\text { Profit } \\
\end{array}$ & Nilai (RP) \\
\hline Delivery Value & 110.000 .000 \\
\hline Acquisition Value & - 110.000 .000 \\
\hline Extra VAT Pay & 10.000 .000 \\
\hline Profit & 10.000 .000 \\
\hline
\end{tabular}

Source: Personal Illustration
Based on Table 6, it can be seen that the mechanism of PK-PM between Unpaid VAT Unpaid is the same as PPT DTP. Where prices for end consumers will be lower than regular transactions. However, in terms of PKP and Government administrative burden, it will increase. Where in PMK-28 / PMK.03 / 2020, PKP is obliged to make a list of realization of PPN DTP, which is an additional report other than SPT for the VAT Period itself. As for the Government, the mechanism for paying PPN DTP refers to PMK-237 / PMK.05 / 2011 The following is the budget arrangement based on the PMK:

Figure 2.

\section{P-DTP Budget Line}

Revenue transactions P-DPT recorded with the account code as follows

a. The revenue of income tax's DPT as follows:

1. 411141 (Article $21 \mathrm{PPH}$ income is borne by the government);

2. 411142 (Article $22 \mathrm{PPH}$ income is borne by the government);

3. 411143 (Article $22 \mathrm{PPH}$ income for import goods is borne by the government);

4. 411144 (Article $23 \mathrm{PPH}$ income is borne by the government);

5. 411145 (Article 25/29 PPH income for personal goods is borne by the government);

6. 411146 (Article 25/29 PPH income for agency is borne by the government);

7. 411147 (Article $26 \mathrm{PPH}$ income is borne by the government);

8. 411148 (final pph income is borne by the government);

9. 411149 (PPH income for non oil and gas is borne by the government).

b. The revenue of Value-added tax as follows:

1. 411231 (Domestic VAT revenue is borne by the government);

2. 411232 (VAT import income is borne by the government);

3. 411239 (Other VAT income is borne by the government).

c. The revenue of other tax income as follows:

1. 411631 (billing interest income of income tax is borne by the government);

2. 411632 (billing interest income of value-added tax is borne by the government).

P-DTP subsidy expenditure transactions are recorded with the following account code

a. 551321 (expenditure of income tax subsidies borne by the government)

b. 551322 (expenditure of valu-added tax subsidies borne by the government)

Sumber: Caption PMK-237/PMK.05/2011 (2020) 
Based on Figure 2, there is a P-DTP subsidy expenditure budget on the expenditure side, and in terms of revenue, there is a P-DTP income budget. The term is out the right container, into the left container.

\section{Results of Discussion on Comparison of VAT Facilities in the PPN and DTP PPN Law on Covid-19.}

The author also wants to compare the VAT facilities based on the VAT Act with the PPN DTP on Covid-19 Disasters. First, the author prefers to use the word incentive for DTP VAT even though in PMK-28 / PMK.03 / 2020, DTP VAT is included in the category of tax facilities because if using the word facility, DTP VAT is not accommodated in the VAT Act. This problem has also become the BPK's findings, as discussed earlier. The provision of tax incentives is widely used by the government in several countries to be used in social policies (Porter, 1970). Based on the VAT Law, VAT facilities are more used in economic improvement policies.

Secondly, in fact, in the VAT Act, VAT facilities can be provided to "assist the availability of Taxable Goods and Taxable Services needed in the framework of handling natural disasters that are determined as national natural disasters." The Covid-19 outbreak was declared a national disaster by the government. All VAT related transactions should be provided with VAT facilities. But the provision of these facilities must be based on PP, while according to the author's analysis, the issuance of PP takes a long time while the need for this facility is urgent. So that providing PPN DTP incentives through PMK can accelerate the process of handling the Covid-19 outbreak. Besides, the provision of VAT facilities tends to be long-term, while the need for managing the Covid-19 epidemic is not expected to be too long so that the standard VAT mechanism can run again without having to change PP.

Finally, by providing PPN DTP incentives, the performance of tax revenue is not disrupted. The tax ratio is also maintained, although the source comes from the expenditure side of the budget. It is needed to keep Indonesia in increasing the Tax Ratio. Also, DGT, as an institution in collecting tax revenues, performance remains excellent. Where the target set is expected to be achieved, another thing that can be added is the provision of DTP VAT incentives, based on simulations it should reduce prices. At the same time, this policy does not harm PKP. So that in terms of social and economic, all are expected to benefit.

\section{Results of Discussion on Comparison of Covid-19 DTP VAT and Other DTP VAT.}

The significant impact of the Covid-19 outbreak on Indonesia's social and economic aspects is quite substantial. The government is trying to find a way out of dealing with the plague. One of the policies in helping the handling of the Covid-19 outbreak is to provide PPN DTP incentives. Based on the literature review that has been done, the writer tries to compare the PPN DTP over the handling of the Covid-19 Plague with other DTP PPN that have been given. There are some differences between the PPN DTP for the Covid-19 outbreak and other DTP PPN. The difference is among others in the PPT DTP over the Covid-19 outbreak, objects that get many and varied facilities. It is because in dealing with the Covid-19 pandemic, many related objects are used in handling the Covid-19 epidemic, whereas other VAT DTP, objectives that get VAT DTP incentives are more specific. As well, the provision of DTP VAT incentives for the Covid-19 outbreak was limited to only a few months. The government hopes that the Covid-19 pandemic can be dealt with immediately, whereas another VAT DTP is usually valid within one fiscal year.

Also, there are some similarities between the PPN DTP over the Covid-19 outbreak with other DTP PPN. The equation can be seen from the mechanism of providing incentives. The mechanism used uses the same legal basis. Another similarity is that the granting of VAT DTP is based on urgent conditions where the tax instrument as an improved function is needed.

\section{CONCLUSION}

Based on testing the problems in this study, it can be explained that the VAT Law does not accommodate the provision of incentives for PPN DTP. Even so, the rule of PPN DTP incentives uses the legal basis of the APBN Law. Where the PK-PM mechanism is still running, only the tax burden is borne by the government. In the future, PPN DTP can be accommodated by the VAT Act or the VAT Act facility can be provided through the authority of the Minister of Finance, to shorten the bureaucracy.

Tests on the rules of PPN DTP incentives show that these incentives are issued to help the community deal with problems that are urgent in their handling. Of the many PPN DTP incentives, almost the majority is done to improve society's economic and social aspects. Providing PPN DTP incentives for the Covid-19 outbreak is expected to assist the government in dealing with the Covid-19 epidemic that threatens public health. The provision of PPN DTP incentives is also likely to provide lower selling prices, without harming PKP. So PKP can still make a profit while delivering BKP / JKP at a low price. By not reducing the PKP profit, it is hoped that the production of BKP / JKP used in handling the Covid-19 outbreak will continue.

The findings of this study are expected to add implications for the research of PPN DTP, especially PPN DTP, for handling the Covid-19 outbreak. Besides, this study was able to add to the author's insight into the application of VAT facilities. This paper is also expected to provide input for the government in making regulations on VAT facilities. The writing of this research also has several limitations. The limitations in this study which may lead to inaccuracies in the results of the study include: 
1. This research only uses literature studies and several numbers of illustrations, without using actual number data and real events in the field.

2. Research subjects taken are limited to PPN DTP, while the facilities provided by PMK-28 / PMK.03 / 2020 are not limited to VAT facilities provision.

3. Limit observations only to the submission of BKP / JKP that gets DTP PPN facilities, without discussing DTP PPN facilities on BKP imports or the use of intangible JKP / BKP from outside the customs area.

\section{REFERENCES}

Yang, M., Shang, Y., Tian, Z., Xiong, M., Lu, C., Jiang, Y., Zhang, Y., Zhang, Y., Jin, X., Jin, Q., Zhang, Y., Willcox, M. L., \& Liu, J. (2020). Characteristics of registered studies for Coronavirus disease 2019 (COVID-19): A systematic review. Integrative Medicine Research. https://doi.org/10.1016/j.imr.2020.100426.

Peraturan Direktur Jenderal Pajak Nomor PER - 24/PJ/2012 Tentang Bentuk, Ukuran, Tata Cara Pengisian Keterangan, Prosedur Pemberitahuan Dalam Rangka Pembuatan, Tata Cara Pembetulan Atau Penggantian, Dan Tata Cara Pembatalan Faktur Pajak, (2012).

Peraturan Pemerintah Pengganti Undang-Undang Nomor 1 Tahun 2020 tentang Kebijakan Keuangan Negara Dan Stabilitas Sistem Keuangan Untuk Penanganan Pandemi Corona Virus Disease 2019 (Covid-19) dan/atau Dalam Rangka Menghadapi Ancaman yang Membahayakan Perekonomian Nasional dan/atau Stabilitas Sistem Keuangan, 1 C.F.R. (2020).

Peraturan Menteri Keuangan Republik Indonesia Nomor 25/PMK.011/2010 Tentang Pajak Pertambahan Nilai Ditanggung Pemerintah Atas Penyerahan Minyak Goreng Kemasan Sederhana Di Dalam Negeri Untuk Tahun Anggaran 2010, (2010).

Peraturan Menteri Keuangan Republik Indonesia Nomor 26/PMK.011/2011 Tentang Pajak Pertambahan Nilai Ditanggung Pemerintah Atas Penyerahan Minyak Goreng Kemasan Sederhana Di Dalam Negeri Untuk Tahun Anggaran 2011, (2011).

Peraturan Menteri Keuangan RI nomor 28/PMK.03/2020 tentang Pemberian Fasilitas Pajak Terhadap Barang Dan Jasa Yang Diperlukan Dalam Rangka Penanganan Pandemi Corona Virus Disease 2019, (2020).

Peraturan Menteri Keuangan Republik Indonesia Nomor 29/PMK.011/2011 Tentang Pajak Pertambahan Nilai Ditanggung Pemerintah Atas Penyerahan Minyak Goreng Sawit Curah Di Dalam Negeri Untuk Tahun Anggaran 2011, (2011).
Peraturan Menteri Keuangan Republik Indonesia Nomor 88/PMK.011/2011 Tentang Pajak Pertambahan Nilai Ditanggung Pemerintah Atas Subsidi Bahan Bakar Minyak Jenis Tertentu Dan Liquefied Petroleum Gas (Lpg) Tabung 3 (Tiga) Kilogram Bersubsidi Tahun Anggaran 2011, (2011).

Peraturan Menteri Keuangan Republik Indonesia Nomor 215/PMK.03/2010 Tentang Pajak Pertambahan Nilai Ditanggung Pemerintah Atas Subsidi Bahan Bakar Minyak, Bahan Bakar Nabati Dan Liquefied Petroleum Gas (LPG) Tabung 3 (Tiga) Kilogram Bersubsidi Tahun Anggaran 2010, (2010).

Peraturan Menteri Keuangan Republik Indonesia Nomor 228/PMK.05/2010 Tentang Mekanisme Pelaksanaan dan Pertanggungjawaban atas Pajak Ditanggung Pemerintah, (2010).

Peraturan Menteri Keuangan Republik Indonesia Nomor 237/PMK.05/2011 Tentang Perubahan atas Peraturan Menteri Keuangan Nomor 228/PMK.05/2010 Tentang Mekanisme Pelaksanaan dan Pertanggungjawaban atas Pajak Ditanggung Pemerintah, (2011).

Peraturan Menteri Keuangan Republik Indonesia Nomor 251/PMK.011/2010 Tentang Pajak Pertambahan Nilai Ditanggung Pemerintah Atas Transaksi Murabahah Perbankan Syariah Tahun Anggaran 2010, (2010).

Peraturan Pemerintah Republik Indonesia Nomor 10 Tahun 2012 Tentang Perlakuan Kepabeanan, Perpajakan, Dan Cukai Serta Tata Laksana Pemasukan Dan Pengeluaran Barang Ke Dan Dari Serta Berada Di Kawasan Yang Telah Ditetapkan Sebagai Kawasan Perdagangan Bebas Dan Pelabuhan Bebas, (2012).

Peraturan Pemerintah Nomor 21 Tahun 2020 tentang Pembatasan Sosial Beskala Besar Dalam Rangka Percepatan Penanganan Corona Virus Disease 2019 (COVID-19), 21 C.F.R. (2020).

Peraturan Pemerintah Republik Indonesia Nomor 38 Tahun 2003 Tentang Perubahan Atas Peraturan Pemerintah Nomor 146 Tahun 2000 Tentang Impor Dan Atau Penyerahan Barang Kena Pajak Tertentu Dan Atau Penyerahan Jasa Kena Pajak Tertentu Yang Dibebaskan Dari Pengenaan Pajak Pertambahan Nilai, (2003).

Peraturan Pemerintah Republik Indonesia Nomor 40 Tahun 2015 Tentang Penyerahan Air Bersih Yang Dibebaskan Dari Pengenaan Pajak Pertambahan Nilai, (2015).

Peraturan Pemerintah Republik Indonesia Nomor 50 Tahun 2019 Tentang Impor Dan Penyerahan Alat Angkutan Tertentu Serta Penyerahan Dan Pemanfaatan Jasa 
Kena Pajak Terkait Alat Angkutan Tertentu Yang Tidak Dipungut Pajak Pertambahan Nilai, (2019).

Peraturan Pemerintah Republik Indonesia Nomor 81 Tahun 2015 Tentang Impor Dan/Atau Penyerahan Barang Kena Pajak Tertentu Yang Bersifat Strategis Yang Dibebaskan Dari Pengenaan Pajak Pertambahan Nilai, (2015).

Peraturan Pemerintah Republik Indonesia Nomor 106 Tahun 2015 Tentang Penyerahan Barang Kena Pajak Tertentu Yang Bersifat Strategis Yang Tidak Dipungut Pajak Pertambahan Nilai, (2015). 